Profit: Jurnal Kajian Ekonomi dan Perbankan 2 (1) 2018. P: 35-49

PROFIT : JURNAL KAJIAN EKONOMI DAN PERBANKAN

https://ejournal.unuja.ac.id/index.php/profit

E-ISSN : 2597-9434, ISSN: 26854309

\title{
Analisis Permintaan dan Perilaku Konsumen Fintech Syariah Model Crowdfunding
}

Lilik Rahmawati, Baiq el
Badriati \& Iqbal Tanjung*

- FEBI UIN Sunan Ampel Surabaya, UIN Mataram, IAIN Padangsidimpuan

Email :baiqelbadriati@gmail.com, lilikrahmawati@uinsby.ac.id

\section{Abstract:}

Pengetahuan dan pemahaman terkait permintaan dan perilaku konsumen bagi seorang manajer atau produsen adalah hal yang sangat penting terutama di era digital. Pada tulisan ini, selain membahas tentang konsep permintaan dan perilaku konsumen penulis juga membahas terapan konsep permintaan dan perilaku konsumen pada industri fintech dalam skema crowdfunding syariah. Crowdfunding syariah adalah sebuah bisnis yang memanfaatkan platform sebagai medianya untuk pengumpulan dana sekaligus pendanaan bagi individu, kelompok atau organisasi dengan prinsip syariah. Preferensi konsumen di era digital telah mengalami pergeseran. Konsumen menginginkan kecepatan, kenyamanan, biaya yang lebih murah, dan kemudahan penggunaan layanan keuangan. Manajer atau pengusaha di bidang industri fintech dalam skema crowdfunding syariah harus mampu beradaptasi terhadap pergeseran preferensi konsumen dengan cara terus menerus melakukan inovasi.

Keyword: Crowdfunding, Preferensi, Konsumen 


\section{PENDAHULUAN}

Pengetahuan dan pemahaman terkait konsumen bagi seorang manajer atau produsen adalah hal yang sangat penting. Oleh karena itu, pengetahuan mengenai permintaan barang atau jasa yang dijual merupakan komponen penting dan strategis dalam bisnis karena erat kaitannya dengan hasil penjualan yang akan diperoleh yang pada gilirannya akan mempengaruhi tingkat keuntungan yang akan diraihnya nanti. Bagaimanapun efisiensinya suatu proses produksi serta didukung oleh manajer yang handal, tetapi bila permintaan akan barang atau jasa yang dijualnya mengalami penurunan maka mustahil sebuah perusahaan akan dapat survive.

Banyak perusahaan gulung tikar karena tidak mampu mempertahankan tingkat penjualan yang minimal, atau dengan kata lain permintaan terhadap barang yang dijualnya menunjukkan trend yang semakin menurun. Dengan kata lain, kegagalan perusahaan untuk mempertahankan pangsa pasar yang telah diraih merupakan salah satu faktor utama mengapa banyak perusahaan tidak mampu bertahan dalam jangka waktu yang lebih lama. Jika suatu perusahaan menghadapi permintaan yang sering berfluktuasi, sudah barang tentu dituntut untuk mampu memperkirakan secara tepat bagaimana kemungkinan permintaan dimasa yang akan datang. Keberhasilan memperkirakan permintaan di masa datang merupakan informasi berharga bagi manajemen untuk secara tepat pula menentukan berapa jumlah produksi yang harus dihasilkan, kemudian berapa biaya produksi yang dibutuhkan, dan pada akhirnya dapat pula diperkirakan berapa kira-kira keuntungan yang akan diperolehnya.

Dengan demikian informasi mengenai permintaan yang akan datang merupakan landasan bagi perencanaan kegiatan perusahaan secara keseluruhan, sehingga kekurangcermatan dalam perencanaan terhadap seluruh kegiatan perusahaan dapat dihindarkan sekecil mungkin. Singkatnya, kelangsungan hidup suatu perusahaan sangat ditentukan oleh kemampuannya untuk mempertahankan dan meningkatkan permintaan terhadap barang yang dijualnya

Manajer maupun produsen tidak hanya dituntut untuk meningkatkan permintaan suatu produk, namun juga harus mempunyai skill dalam menciptakan produk yang memiliki nilai tambah atau nilai lebih sesuai kebutuhan dan keinginan konsumen. Tentunya dengan memahami bagaimana perilaku konsumen, maka produsen akan mampu memberikan kepuasan kepada konsumen, terutama di era perkembangan teknologi informasi atau dikenal era digital.

Saat ini gelombang revolusi dalam teknologi digital secara cepat dan massif merangsek masuk ke hampir semua aspek kehidupan dan ekonomi masyarakat dunia, seperti transportasi, kesehatan, pendidikan, ritel, hotel, dan bahkan keuangan. Di sektor keuangan kini berkembang 
konsep fintech. Fintech didefinisikan sebagai inovasi teknologi dalam layanan keuangan yang dapat menghasilkan model-model bisnis, aplikasi, proses atau produk-produk dengan efek material yang terkait dengan penyediaan layanan keuangan. ${ }^{1}$ Dengan model bisnis dan aplikasi teknologi baru memungkinkan munculnya pemain-pemain baru di sektor jasa keuangan.

Sebagaimana bisnis pada umumnya, menjalankan bisnis di sektor fintech membutuhkan pengetahuan dan pemahaman akan konsep permintaan dan perilaku konsumen. Oleh karena itu, penguasaan akan konsep permintaan dan perilaku konsumen bagi pengusaha di sektor fintech yang diteruskan dalam keputusan bisnis yang tepat akan menentukan keberhasilan bisnis yang dijalankan.

Pada tulisan ini, selain membahas tentang konsep permintaan dan perilaku konsumen penulis juga membahas terapan konsep permintaan dan perilaku konsumen pada industri fintech dalam skema crowdfunding syariah. Crowdfunding syariah, sebuah bisnis yang memanfaatkan platform sebagai medianya untuk pengumpulan dana sekaligus pendanaan bagi individu, kelompok atau organisasi dengan prinsip syariah.

\section{PEMBAHASAN}

A. Permintaan

\section{Definisi Permintaan}

Secara umum, permintaan adalah jumlah barang atau jasa tertentu yang konsumen mau beli pada kondisi dan waktu tertentu. Dalam ilmu ekonomi istilah permintaan (demand) mempunyai arti tertentu, yaitu selalu menunjuk pada suatu hubungan tertentu antara jumlah suatu barang atau jasa yang akan dibeli orang dan harga barang atau jasa tersebut. Permintaan adalah jumlah dari suatu barang atau jasa yang mau dan mampu dibeli pada berbagai kemungkinan harga, selama jangka waktu tertentu, dengan anggapan hal-hal lain tetap sama atau cateris paribus. ${ }^{2}$

\section{Faktor-Faktor yang Mempengaruhi Permintaan}

Menurut Sukirno, permintaan seseorang atau suatu masyarakat terhadap suatu barang ditentukan oleh banyak faktor, dimana faktor - faktor yang terpenting adalah dinyatakan sebagai berikut $^{3}$ :

a. Harga barang itu sendiri

\footnotetext{
${ }^{1}$ Financial Stability Board (FSB, 2017a). FinTech credit : Market structure, business models and financial stability implications. May 2017.

${ }^{2}$ T. Gilarso, Pengantar Ilmu Ekonomi Makro Edisi Pertama, (Yogyakarta: IKAPI, 2007), 57. ${ }^{3}$ Sadono Sukirno, Mikro Ekonomi, Teori Pengantar, (Jakarta: PT. Raja Grafindo Persada, 2005), 43.
} 
b. Harga barang lain yang berkaitan erat dengan barang tersebut

c. Pendapatan rumah tangga dan pendapatan rata - rata masyarakat

d. Corak distribusi pendapatan dalam masyarakat

e. Cita rasa masyarakat

f. Jumlah penduduk

g. Ramalan mengenai keadaan di masa yang akan datang

Sedangkan menurut Rahardja, faktor - faktor yang mempengaruhi permintaan antara lain sebagai berikut : ${ }^{4}$

a. Harga barang itu sendiri

b. Harga barang lain yang terkait

c. Tingkat pendapatan perkapita

d. Selera atau kebiasaan konsumen

e. Jumlah Penduduk

f. Perkiraan harga di masa mendatang

g. Distribusi pendapatan

h. Usaha - usaha produsen meningkatkan penjualan

Penjelasan tentang teori permintaan, ahli ekonomi membuat analisis yang lebih sederhana, hal ini di sebabkan dalam analisis ekonomi bahwa permintaan suatu barang terutama dipengaruhi oleh tingkat harga. Teori permintaan yang dianalisis adalah hubungan antara jumlah permintaan suatu barang dengan harga barang yang tersebut.

Dalam analisis tersebut diasumsikan bahwa faktor - faktor lain tidak mengalami perubahan atau ceteris paribus. Tetapi dengan asumsi yang dinyatakan ini tidaklah berarti bahwa kita dapat mengabaikan faktor - faktor yang dianggap tetap tersebut.Setelah menganalisis hubungan antara jumlah permintaan dan tingkat harga maka selanjutnya boleh mengasumsikan bahwa harga adalah tetap dan kemudian menganalisis bagaimana permintaan suatu barang dipengaruhi oleh berbagai faktor lainnya. Dengan demikian dapat diketahui bagaimana permintaan terhadap suatu barang akan berubah apabila cita rasa atau pendapatan atau harga barang - barang lain mengalami perubahan pula. $^{5}$

\section{Fungsi Permintaan dan Kurva Permintaan}

${ }^{4}$ Prathama Rahardja dan Mandala Manurung, Teori Ekonomi Makro Suatu Pengantar Edisi Kedua, (Jakarta, Lembaga Peneit FEUI, 2004), 12.

${ }^{5}$ Sadono Sukirno, op. cit, 49.

38 Profit : Jurnal Kajian Ekonomi dan Perbankan 
Permintaan yang dinyatakan dalam hubungan matematis dengan faktor-faktor yang memengaruhinya disebut fungsi permintaan. Fungsi permintaan menghubungkan antara variabel bebas dengan variabel tidak bebas Secara matematis hal itu dapat dirumuskan dalam formula sebagai berikut :

$$
D_{x}=f(P x, Y, P y, T, u)
$$

Keterangan:

$\mathrm{Dx}=$ jumlah barang yang diminta

Px $=$ harga barang itu sendiri

$\mathrm{Y}=$ pendapatan konsumen

Py $=$ harga barang lain

$\mathrm{T}=$ selera

$\mathrm{u}=$ faktor - faktor lainnya.

Dx adalah variabel tidak bebas, karena besarnya nilai ditentukan oleh variable lain. Px, Y, Py, Y, T dan u adalah variabel bebas karena besar nilainya tidak tergantung besarnya variabel lain. Tanda positif dan negatif menunjukkan pengaruh masing-masing variabel bebas terhadap permintaan akan barang.

Kurva permintaan adalah kurva yang menghubungkan antara harga barang (ceteris paribus) dengan jumlah barang yang diminta. Kurva permintaan menggambarkan tingkat maksimum pembelian pada harga tertentu, ceteris paribus (keadaan lain tetap sama). Berikut ini digambarkan kurva permintaan pada Gambar 1.

\section{Gambar 1: Kurva Permintaan}

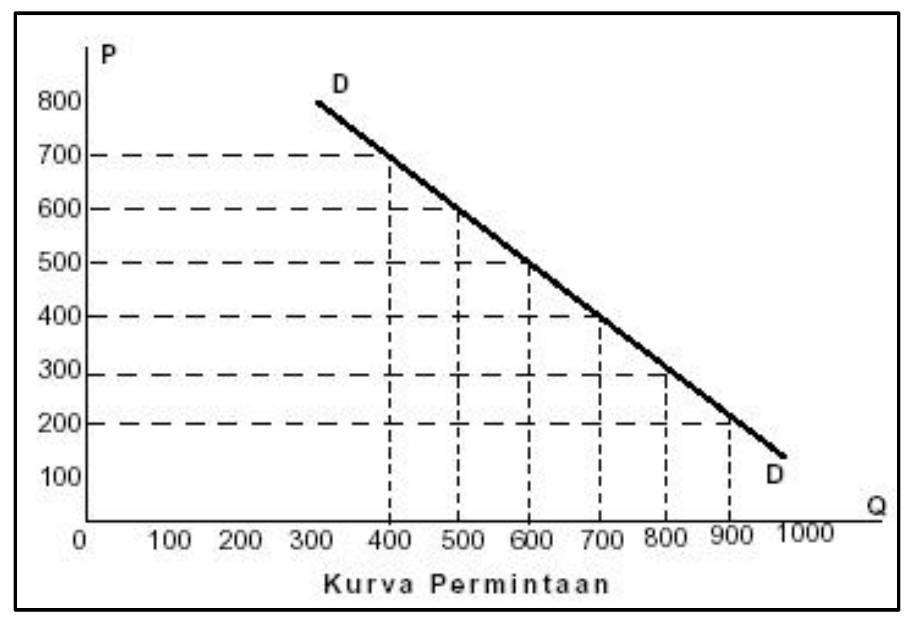

Kenaikan harga produk (ceteris paribus) akan menyebabkan penurunan jumlah barang yang diminta yang berarti terjadi perpindahan di sepanjang kurva permintaan. Perubahan variabel non- 
harga akan menyebabkan pergeseran kurva permintaan, atau menyebabkan perubahan jumlah barang yang diminta pada tingkat harga tertentu. Faktor-faktor yang menyebabkan pergeseran permintaan diantaranya adalah perubahan pendapatan, selera, harga barang lain dan jumlah populasi. Perubahan permintaan akan digambarkan dengan pergeseran kurva permintaan ke atas atau ke bawah. ${ }^{6} \mathrm{Gambar}$ pergeseran kurva permintaan ditunjukkan pada gambar 2.

Gambar 2: Pergeseran Kurva Permintaan

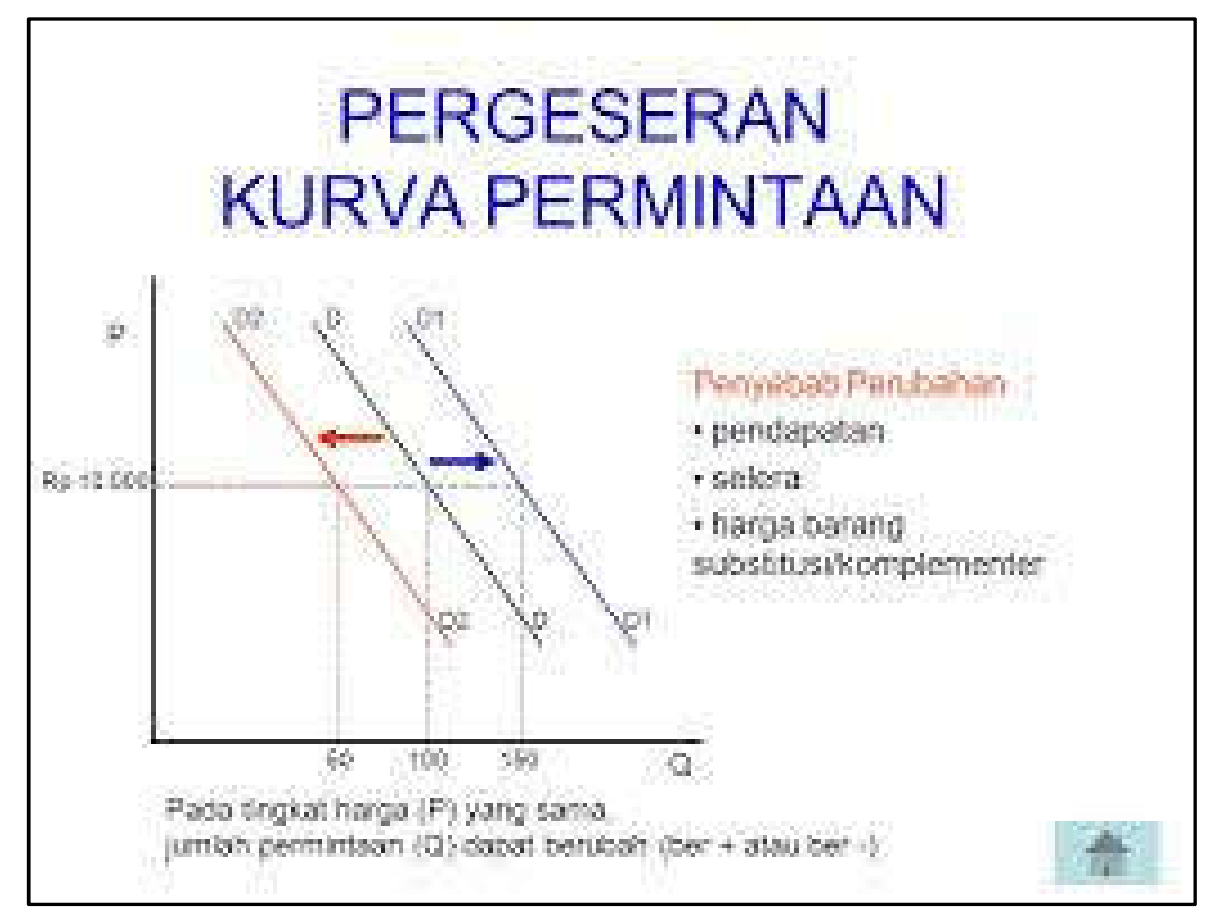

Perubahan harga barang lain berpengaruh pada pergeseran kurva permintaan. Kenaikan harga barang substitusi (yang bersifat saling menggantikan) menggeser kurva permintaan komoditi ke kanan, lebih banyak yang dibeli pada setiap tingkat harga. Kenaikan harga barang komplementernya (komoditi yang digunakan secara bersama-sama) akan menggeser kurva permintaan ke kiri. Hal ini akan terjadi Pertumbuhan jumlah populasi atau penduduk akan menciptakan permintaan baru. Penduduk yang bertambah ini harus memiliki daya beli sebelum permintaan berubah.Adanya faktor Peningkatan orang berusia kerja, tentunya akan menciptakan pendapatan baru. Jika ini terjadi, permintaan untuk semua komoditi yang dibeli oleh penghasil pendapatan baru akan meningkat. Kenaikan jumlah penduduk akan menggeser kurva permintaan untuk komoditi ke arah kanan, yang menunjukkan bahwa akan lebih banyak komoditi yang dibeli pada setiap tingkat harga.

'Suhartati Joesron dan M.Fathorrozi, Teori Ekonomi Mikro, (Jakarta: Salemba Empat, 2003), 77. 


\section{B. Perilaku Konsumen}

\section{Konsep Perilaku Konsumen}

Kebutuhan dan keinginan konsumen sangat bervariasi dan dapat berubah ubah karena adanya faktor-faktor yang mempengaruhi konsumen dalam melakukan pembelian. Oleh karena itu, seorang pebisnis, manajer, maupun pemasar perlu untuk memahami perilaku konsumen supaya kegiatan pemasaran yang dilaksanakan dapat berjalan secara efektif dan efisien. Ada beberapa pengertian perilaku konsumen yang dikemukakan oleh para ahli diantaranya adalah:

a. Mangkunegara : "Perilaku konsumen adalah tindakan-tindakan yang dilakukan oleh individu, kelompok atau organisasi yang berhubungan dengan proses pengambilan keputusan dalam mendapatkan, menggunakan barang-barang atau jasa ekonomis yang dapat dipengaruhi lingkungan". 7

b. Menurut Winardi dalam Sumarwan: "Perilaku konsumen adalah perilaku yang ditujukan oleh orang-orang dalam merencanakan, membeli dan menggunakan barang-barang ekonomi dan jasa". 8

Pemahaman terhadap perilaku konsumen bukanlah pekerjaan yang mudah, tetapi cukup sulit dan kompleks.Hal ini disebabkan oleh banyaknya variabel variabel yang mempengaruhinya dan variabel-variabel tersebut cenderung saling berinteraksi. Meskipun demikian, apabila hal tersebut dapat dilakukan, maka suatu perusahaan penghasil barang maupun jasa akan dapat meraih keuntungan yang jauh lebih besar daripada perusahaan pesaingnya karena dengan memahami perilaku konsumen maka perusahaan tersebut dapat memberikan kepuasan secara lebih baik kepada konsumennya.

Dari beberapa definisi di atas, maka penulis dapat menarik kesimpulan bahwa yang dimaksud dengan perilaku konsumen adalah sejumlah tindakan tindakan nyata individu (Konsumen) yang dipengaruhi oleh faktor-faktor internal dan eksternal yang mengarahkan mereka untuk menilai, memilih, mendapatkan dan menggunakan barang dan jasa yang diinginkannya.

\section{Faktor-faktor Yang Mempengaruhi Perilaku Konsumen}

Dalam pengambilan sebuah keputusan, seorang manajer harus memahami perilaku konsumen, manajer akan mengetahui pemasaran yang tepat ataupun kesempatan baru yang berasal

${ }^{7}$ Anwar Prabu Mangkunegara, Perilaku Konsumen, (Bandung: Refika, 2003), 14.

${ }^{8}$ Ujang Sumarwan, Perilaku Konsumen, (Jakarta: Ghaiia Indonesia, 2003), 22.

\section{Profit : Jurnal Kajian Ekonomi dan Perbankan}


dari belum terpenuhinya kebutuhan serta kemudian mengidentifikasikan untuk mengadakan segmentasi pasar. Banyak faktor yang mempengaruhi perilaku konsumen dalam membuat keputusan pembelian.Secara garis besar faktor-faktor yang mempengaruhi perilaku konsumen dibagi menjadi dua bagian yaitu eksternal dan faktor internal.

Menurut Setiadi, faktor-faktor internal individual yang mempengaruhi perilaku konsumen seperti : 1) motivasi, 2) kepribadian, 3) pembelanjaan, 4) sikap, 5) persepsi konsumen. Selain faktorfaktor lingkungan internal, faktor-faktor eksternal individu juga sangat berpengaruh terhadap perilaku pembelian konsumen. Menurut Setiadi faktor-faktor lingkungan ekstern yang mempengaruhi perilaku konsumen meliputi: 1) kelompok rujukan, 2) kelas sosial, 3) budaya, 4) komunikasi. $^{9}$

Sementara konsep Swastha dan Handoko menyatakan bahwa faktor-faktor psikologis yang berasal dari proses intern individu sangat berpengaruh terhadap perilaku pembelian konsumen. Faktor-faktor psikologis yang menjadi faktor dasar dalam perilaku konsumen adalah : 1) motivasi, 2) pengamatan, 3) belajar, 4) kepribadian dan konsep diri, dan 5) sikap. Sementara itu faktor-faktor lingkungan ekstern yang mempengaruhi perilaku konsumen yaitu : 1) kebudayaan (culture) dan kebudayaan khusus (subculture), 2) kelas sosial (social class), 3) kelompok-kelompok sosial (social group), kelompok referensi (referensi group), dan 4) keluarga (family)". ${ }^{10}$

\section{Keputusan Pembelian}

Semua kegiatan yang dilakukan perusahaan melalui pemasaran diharapkan dapat mempengaruhi konsumen sehingga sampai pada keputusan pembelian.Sedangkan keputusan pembelian dapat diartikan sebagai keputusan konsumen untuk membeli produk dengan didasari oleh adanya niat untuk melakukan pembelian dengan melalui beberapa tahap. Perilaku konsumen akan menentukan proses pengambilan keputusan dalam pembelian mereka.

Keputusan merupakan salah satu kegiatan yang dilakukan oleh setiap orang dalam setiap waktu dan di segala tempat. Keputusan tersebut termasuk keputusan yang menyangkut kegiatan individu. Mempengaruhi keputusan konsumen yang dilakukan secara efektif akan mempengaruhi pengambilan keputusan. Ini berarti meningkat pula tingkat keuntungan yang diperoleh.Keputusan konsumen atau organisasi adalah aktivitas yang dilakukan secara sadar, rasional dan terencana.Keputusan konsumen merupakan analisis mengatasi permasalahan. Berdasarkan

${ }^{9}$ Nugroho J. Setiadi, Perilaku Konsumen, (Jakarta: kencana, 2003), 17.

${ }^{10}$ Basu DH Swastha dan Handoko T. Hani, Manajemen Pemasaran, Analisis Perilaku Konsumen, (Yogyakarta: BPFE-UGM, 2000), 25. 
pengertian dari Lupiyoadi dijelaskan bahwa keputusan konsumen adalah suatu keputusan konsumen untuk membeli atau menggunakan jasa tertentu yang ditawarkan dengan didasari adanya niat untuk melakukan pembelian/menggunakan jasa. ${ }^{11}$ Manajer maupun pemasar harus meneliti konsumen untuk mengetahui jenis masalah atau keinginan dan kebutuhan yang timbul, apa yang menyebabkan rasa kebutuhan itu dan bagaimana rasa kebutuhan itu mengarah pada obyek tertentu. Sutisna menjelaskan mengenai keputusan pembelian sebagai berikut : Pengambilan keputusan oleh konsumen untuk melakukan pembedaan suatu produk diawali oleh adanya kesadaran atas pemenuhan kebutuhan dan keinginan.. ${ }^{12}$

\section{Analisis Permintaan dan Perilaku Konsumen Crowdfunding Syariah}

Fintech berasal dari istilah financial technology atau teknologi finansial.Fintech didefinisikan sebagai aplikasi teknologi digital untuk masalah-masalah intermediasi keuangan. ${ }^{13}$ Fintech juga didefinisikan sebagai inovasi teknologi dalam layanan keuangan yang dapat menghasilkan modelmodel bisnis, aplikasi, proses atau produk-produk dengan efek material yang terkait dengan penyediaan layanan keuangan. ${ }^{14}$ Dalam arti yang lebih luas, fintech terlihat sebagai pasar baru yang memadukan keuangan dan teknologi dan menggantikan struktur keuangan tradisional dengan proses berbasis teknologi baru. ${ }^{15}$

Fintech atau teknologi keuangan pada umumnya digunakan untuk menunjukkan perusahaan yang menawarkan teknologi modern di sektor keuangan.Perusahaan-perusahaan tersebut telah menjadi tren yang nyata sejak tahun 2010.Perusahaan-perusahaan Fintech kebanyakan adalah perusahaan mikro, kecil atau menengah yang tidak memiliki banyak ekuitas, tetapi memiliki gagasan yang jelas tentang bagaimana memperkenalkan bisnis baru atau bagaimana meningkatkan layanan dalam industri keuangan.

Transaksi keuangan melalui fintech meliputi pembayaran, investasi, peminjaman uang, transfer, rencana keuangan dan pembanding produk keuangan. Berdasarkan analisis pengembangan fintech dan kekhasan bisnis ini, teridentifikasi keunggulan komparatif dari fintech diantaranya adalah layanan keuangan yang sangat terstandar dan berbiaya rendah; berbasis internet dan karena itu

\footnotetext{
${ }^{11}$ Rambat Lupiyoadi, Manajemen Pemasaran Jasa: Teori dan Pratik, (Jakarta: PT. Salemba Empat, 2001), 76.

12Sutisna, Perilaku Konsumen dan Komunikasi Pemasaran, (Bandung: Remaja Rosdakarya, 2002), 83.

13 Aaron, M., Rivadeneyra, F., and Sohal, S.(2017). Fintech : Is this time different? A framework for assessing risks and opportunities for Central Banks. Bank of Canada Staff Discussion Paper 2017-10 (July). Canada : Bank of Canada

${ }^{14}$ Financial Stability Board (FSB, 2017a). Fin'Tech credit : Market structure, business models and financial stability implications. May 2017.

${ }_{15}$ Arner, D.W., Barberis, J., and Buckley, R.P.(2015). The evolution of Fin'Tech : A new post-crises paradigm?. University of Hong Kong.
} 
kurang terkonsentrasi secara geografis; mengubah perilaku konsumen; regulasi layanan keuangan yang lebih rendah.

Fintech diakui sebagai satu inovasi paling penting dalam industri keuangan dan berkembang dengan cepat, didorong oleh pemerataaan ekonomi, regulasi yang menguntungkan, dan teknologi informasi. Pembayaran digital menjadi salah satu sektor dalam industri fintech yang paling berkembang di Indonesia.

Selain fintech konvensional, kini fintech syariah di Indonesia sudah mulai berkembang, meskipun regulasi terkait fintech syariah ini belum tersedia.Crowdfunding syariah adalah platform Crowdfunding yang dirancang dengan mematuhi prinsip-prinsip syariah.Crowdfunding syariah dapat didefinisikan sebagai media penggunaan sejumlah dana yang diperoleh dari sejumlah besar individu atau organisasi, untuk mendanai proyek, pinjaman bisnis atau individu, dan kebutuhan lainnya melalui berbasis web online platform sesuai dengan prinsip syariah. ${ }^{16}$ Kini, perkembangan fintech syariah menunjukkan trend yang cukup baik.Menurut catatan Asosiasi Fintech Syariah Indonesia (AFSI), saat ini terdapat 55 fintech syariah yang sudah resmi bergabung di AFSI. ${ }^{17}$

Berdasarkan data tersebut, peluang pasar Fintech Syariah cukup menjanjikan. Hal ini didasarkan pada beberapa hal: ${ }^{18}$ (1) Mayoritas penduduk Indonesia beragama Islam, dan 64\% masih unbanked, sehingga dapat memperbesar jumlah target calon pengguna Fintech syariah; (2) Ekonomi syariah terus mengalami pertumbuhan; (3) Ekonomi syariah, termasuk fintech syariah, didukung dengan teknologi yang mapan; (4) Regulasi untuk Fintech Syariah masih dalam tahap penggarapan, sehingga menciptakan peluang untuk berinovasi melalui Fintech syariah.

Ada beberapa macam skema Fintech Syariah, yang cukup dikenal adalah yang memiliki platform Peer to Peer (P2P) dan crowd funding. Fintech dalam keuangan syariah global lebih didominasi dalam bentuk platform crowdfunding. Sebagai contoh adalah HalalSky dan LaunchGood (USA), The Ethical Crowd Yielders (UK), Pitchin dan Waqf World (Malaysia), serta Ethis Crowd dan Kapital Boost (Singapura). ${ }^{19}$

Crowdfunding Syariah adalah platform Crowdfunding yang dirancang dengan mematuhi prinsip-prinsip syariah. Crowdfunding Syariah dapat didefinisikan sebagai media pengumpulan

\footnotetext{
${ }^{16}$ Materi Seminar Indonesia Shariah Economic Festival - Iggi H. Achsien "Fintech Syariah di Indonesia" Surabaya10/November/2017,18

${ }^{17}$ https://www.republika.co.id/berita/ekonomi/syariah-ekonomi/pmvbi0383/11-fintech-syariah-ditargetkan-terdaftardi-ojk

${ }^{18}$ Kajian Bisnis Fintech Syariah - PT. Telkom Indonesia (Bandung: 2017), 56

${ }_{19}$ Financial Stability Board (FSB, 2017a). FinTech credit : Market structure, business models and financial stability implications. May 2017.
}

$44 \quad$ Profit : Jurnal Kajian Ekonomi dan Perbankan 
sejumlah dana yang diperoleh dari sejumlah besar individu atau organisasi, untuk mendanai proyek, pinjaman bisnis atau individu, dan kebutuhan lainnya melalui berbasis web online platform sesuai dengan prinsip syariah.

Fitur dasar yang mencirikan Crowdfunding Syariah: ${ }^{20}$

1. hanya diinvestasikan untuk proyek atau pembiayaan kegiatan yang halal;

2. tidak menggunakan bunga;

3. keberadaan Dewan Pengawas Syariah atau opini syariah.

Sementara itu model Crowdfunding Syariah sebagai berikut: ${ }^{21}$

1. Berbasis Zakat;

2. Berbasis Infaq - Shadaqah - Waqaf; Berdasarkan Qard al hasan;

3. Berbasis Syirkah (Mudharabah dan Musyarakah),

4. Berbasis Pinjaman (Murabahah, Ijarah, Istishna, dan lain-lain)

Berikut ini ditunjukkan skema crowdfunding syariah pada gambar 3.

\section{Gambar 3: Skema Crowdfunding Syariah}

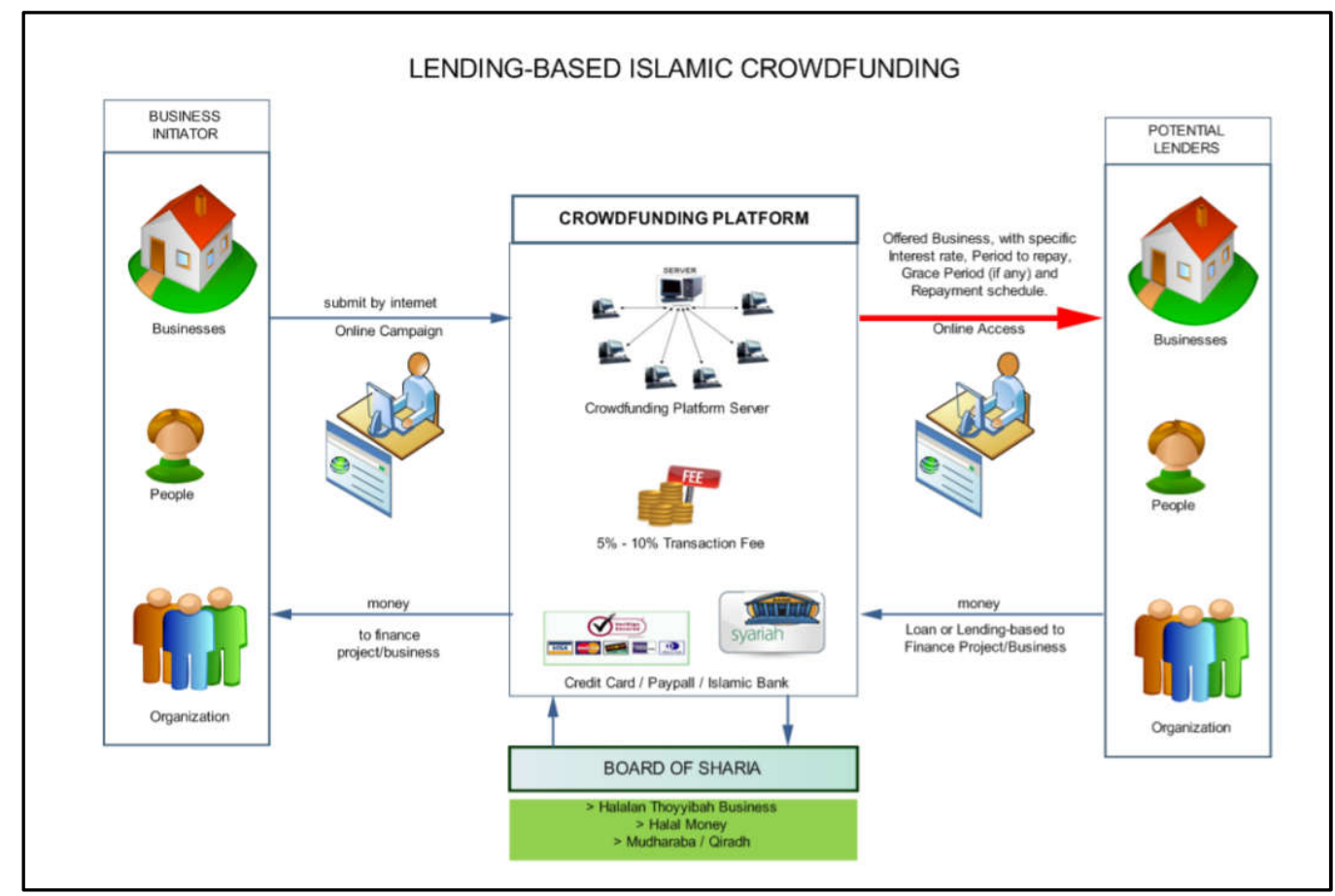

20 Materi Seminar Indonesia Shariah Economic Festival - Iggi H. Achsien "Fintech Syariah di Indonesia" Surabaya10/November/2017, 19-20

${ }^{21}$ Materi Seminar Indonesia Shariah Economic Festival, loc. Cit.

45 Profit : Jurnal Kajian Ekonomi dan Perbankan


Berdasarkan gambar 3, pihak yang menjalankan crowdfunding syariah terbagi menjadi empat, yaitu: ${ }^{22}$

1. Inisiator/Pengaju Proyek, pengaju proyek dapat berupa perorangan, organisasi, dan perusahaan.

2. Penyandang dana potensial, merupakan pihak investor yang berasal dari masyarakat dapat berupa individu maupun berkelompok.

3. Operator crowdfunding, atau disebut juga pihak penyelenggara platform.

4. Dewan Syariah, jika di Indonesia yang dimaksud dewan syariah termasuk DSN-MUI dan DPS.

Merujuk pihak yang menjalankan crowdfunding syariah, maka konsumen fintech crowdfunding syariah bisa diklasifikasikan menjadi dua, pertama adalah Inisiator/Pengaju Proyek, pengaju proyek dapat berupa perorangan, organisasi, dan perusahaan; kedua adalah investor yaitu Penyandang dana potensial, merupakan pihak investor yang berasal dari masyarakat dapat berupa individu maupun berkelompok. Sementara pelaku usaha atau produsennya adalah Operator crowdfunding, atau disebut juga, pihak penyelenggara platform.

Menganalisis bisnis fintech syariah melalui skema crowdfunding, penulis akan membahasnya dalam aspek permintaan dan perilaku konsumen. Dalam konsep permintaan, kenaikan harga produk (ceteris paribus) akan menyebabkan penurunan jumlah barang yang diminta. Merujuk pengertian ini, maka dalam skema crowdfunding yang berbasis syirkah maupun pinjaman, pihak yang membutuhkan dana (pengaju proyek) akan berpatokan terhadap margin yang ditetapkan platform crowdfunding. Jika marginnya yang ditetapkan suatu platform terlalu tinggi, maka pengaju proyek atau pihak yang membutuhkan dana akan mengurungkan niatnya untuk mengajukan pendanaan. Karena bagaimanapun, pengaju proyek tentunya menginginkan margin pinjaman yang ditanggung adalah wajar. Dengan kata lain, pada platform yang menetapkan margin yang tinggi, maka jumlah "barang" yang diminta atau jumlah konsumen yang melakukan pengajuan mengalami penurunan. Keadaan ini sesuai dengan $\mathrm{Hal}$ ini sesuai dengan konsep permintaan. kenaikan harga produk (ceteris paribus) akan menyebabkan penurunan jumlah barang yang diminta.

Satu hal penting yang juga akan menggeser kurva permintaan adalah pengaruh harga barang lain dan selera konsumen. Perubahan harga barang lain berpengaruh pada pergeseran kurva permintaan. Kenaikan harga barang substitusi (yang bersifat saling menggantikan) menggeser kurva permintaan komoditi ke kanan, lebih banyak yang dibeli pada setiap tingkat harga permintaan.Sebagaimana ditunjukkan pada gambar 2 tentang pergeseran kurva permintaan.Dalam

\footnotetext{
${ }^{22}$ Sentot Imam Wahjono, Anna Mariana, and Widayat, Islamic Crowdfunding: Alternative Funding Solution, This paper was presented on 1st World Islamic Social Science Congress 2015, Malaysia, 1-2 December 2015, hal 9.
} 
konsep permintaan, kenaikan harga barang substitusi (yang bersifat saling menggantikan) menggeser kurva permintaan komoditi ke kanan, lebih banyak yang dibeli pada setiap tingkat harga. Artinya, jika platform lain justru menawarkan margin yang lebih tinggi atau meningkatkan nilai margin yang ditetapkan, sehingga dirasa memberatkan bagi pengaju dana, maka secara berbondong-bondong konsumen akan meningkatkan permintaan pada platform awal karena dirasa margin yang ditanggung adalah wajar. Dengan demikian kurva akan mengalami pergeseran komoditi ke kanan.

Sementara itu, pada aspek perilaku konsumen bisa dipahami bahwa perilaku konsumen adalah sejumlah tindakan tindakan nyata individu (konsumen) yang dipengaruhi oleh faktor-faktor internal dan eksternal yang mengarahkan konsumen untuk menilai, memilih, mendapatkan dan menggunakan barang dan jasa yang diinginkan. Jika merujuk pada teori Swasta menyebutkan bahwa faktor-faktor psikologis yang menjadi faktor dasar dalam perilaku konsumen adalah : (1) motivasi, (2) pengamatan, (3) belajar, (4) kepribadian dan konsep diri, dan (5) sikap. Sementara itu faktor-faktor lingkungan ekstern yang mempengaruhi perilaku konsumen yaitu : (1) kebudayaan (culture) dan kebudayaan khusus (subculture), (2) kelas sosial (social class), (3) kelompok-kelompok sosial (social group), kelompok referensi (referensi group), dan (4) keluarga (family)".

Dari pengertian tersebut, maka faktor dasar perilaku konsumen crowdfunding syariah dapat mengambil konsepnya Swasta namun perlu dilengkapi dengan teori Kotler yang mengidentifikasi beberapa faktor yang mempengaruhi konsumen bertransaksi melalui media internet yaitu: ${ }^{23}$

1. Kenyamanan: konsumen tidak perlu bergelut dengan lalu lintas, tidak perlu mencari parkir dan berjalan ke toko atau lembaga keuangan yang dituju

2. Kelengkapan Informasi: konsumen dapat berinteraksi dengan situs penjual atau platform yang menawarkan pinjaman dalam rangka untuk mencari informasi, produk atau jasa yang benarbenar konsumen inginkan, kemudian memesan atau men-download informasi di tempat.

3. Waktu: konsumen dapat memeriksa harga dan memesan barang dagangan selama 24 jam sehari dari mana saja.

4. Kepercayaan konsumen: karena tidak ada tatap muka antara investor dengan pengelola platform ataupun pengaju dana dengan platform, maka transaksi online bertitik tolak pada kepercayaan. Dalam hal ini, konsumen akan mempertaruhkan kerahasiaan data-data pribadi.

Sebagaimana diketahui, transaksi fintech dalam bentuk crowdfunding memanfaatkan media online dan informasi big data. Kenyataan ini meniscayakan adanya pergeseraan preferensi konsumen yang mana akan mempengaruhi permintaan. Konsumen lebih menyukai inovasi. Inovasi

${ }^{23}$ Kotler dan Amstrong. 2001. Manajemen Pemasaran. Penerbit PT. Prehalindo. Yogyakarta. 
akan akses internet yang mudah disertai kemampuan pengguna jaringan internet bertransaksi realtime. Preferensi konsumen fintech memfokus pada aspek yang menyangkut kenyamanan, kecepatan, biaya yang lebih murah, dan kemudahan penggunaan layanan keuangan.

\section{PENUTUP}

Pengetahuan dan pemahaman terkait permintaan dan perilaku konsumen bagi seorang manajer atau produsen adalah hal yang sangat penting terutama di era digital.Kepiawaian produsen dalam menganalisis permintaan dan perilaku konsumen di era digital adalah keniscayaan. Hal ini dikarenakan era digital telah merestrukturisasi model-model bisnis konvensional.Kini, preferensi konsumen telah bergeser.Pada bisnis di sektor keuangan seperti financial technology, konsumen lebih menyukai kenyamanan, kecepatan, biaya yang lebih murah, dan kemudahan penggunaan layanan keuangan. Untuk itu menyikapi karakteristik bisnis financial technology yang berbasis online dan big data meniscayakan produsen untuk terus berinovasi. Dengan berinovasi, seorang manajer atau pemilik platform fintech akan dapat mempertahankan dan meningkatkan tingkat permintaan.

\section{Daftar Pustaka}

D.W.,Arner Barberis, J., and Buckley, R.P.(2015). The evolution of FinTech : A new post-crises paradigm?. University of Hong Kong.

Financial Stability Board (FSB, 2017a). FinTech credit : Market structure, business models and financial stability implications. May 2017.

Gilarso, T, Pengantar Ilmu Ekonomi Makro Edisi Pertama, (Yogyakarta: IKAPI, 2007)

Imam Wahjono, Sentot,Anna Mariana, and Widayat, Islamic Crowdfunding: Alternative Funding Solution, This paper was presented on 1st World Islamic Social Science Congress 2015, Malaysia, 1-2 December 2015.

Joesron, Suhartati dan M.Fathorrozi, Teori Ekonomi Mikro, (Jakarta: Salemba Empat, 2003)

Kajian Bisnis Fintech Syariah - PT. Telkom Indonesia (Bandung: 2017)

Kotler dan Amstrong. 2001. Manajemen Pemasaran. Penerbit PT. Prehalindo. Yogyakarta.

Lupiyoadi, Rambat, Manajemen Pemasaran Jasa: Teori dan Pratik, (Jakarta: PT. Salemba Empat, 2001)

M.,Aaron, Rivadeneyra, F., and Sohal, S.(2017). Fintech : Is this time different? A framework for assessing risks and opportunities for Central Banks. Bank of Canada Staff Discussion Paper 2017-10 (July). Canada : Bank of Canada

Mangkunegara, AP, Perilaku Konsumen, (Bandung: Refika, 2003) 
Materi Seminar Indonesia Shariah Economic Festival - Iggi H. Achsien "Fintech Syariah di Indonesia" Surabaya10/November/2017.

Rahardja, Prathama dan Mandala Manurung, Teori Ekonomi Makro Suatu Pengantar Edisi Kedua, (Jakarta, Lembaga Peneit FEUI, 2004)

Setiadi,Nugroho J, Perilaku Konsumen, (Jakarta: kencana, 2003)

Sukirno, Sadono, Mikro Ekonomi, Teori Pengantar, (Jakarta: PT. Raja Grafindo Persada, 2005)

Sumarwan, Ujang Perilaku Konsumen, (Jakarta: Ghalia Indonesia, 2003)

Sutisna, Perilaku Konsumen dan Komunikasi Pemasaran, (Bandung: Remaja Rosdakarya, 2002)

Swastha,Basu DH dan Handoko T. Hani, Manajemen Pemasaran, Analisis Perilaku Konsumen, (Yogyakarta: BPFE-UGM, 2000) 